\title{
Areas for Benchmarking among SMEs
}

\author{
Norailis Ab. Wahab and Syarizal Abdul Rahim
}

\begin{abstract}
Job creation, economic growth and innovation are partial of the achievement for SMEson the well-being of the economy for a particular country and society. Due to the reasons, there are lots of benchmarking activities conducted by government and private bodies through events that promote exposures for the SMEs in enhancing its capabilities. Thus, this paper aims to identify the areas within benchmarking activities that are implemented by local SMEs. Semi-structured interviews were conducted among 35 SMEs that were willing to participate voluntarily. This study found that management is the best driver of benchmarking adoption. Possibly, the closeness of relationship between management, suppliers and customers enhances support for benchmarking in the enterprises. It also revealed that SMEs benchmarked in only one specific area or in all aspects such as production $(32.6 \%)$, operations management $(\mathbf{1 7 . 0 \%})$, marketing $(\mathbf{1 6 . 0 \%})$, information and communication technology (ICT) application (16.8\%), financial $(\mathbf{1 0 . 0 \%})$, and management (7.0\%). Although the results should be taken with caution, nevertheless benchmarking is vital in facing new challenges and opportunities for success in productivity and profitability.
\end{abstract}

Index Terms - Benchmarking, business, management, small and medium enterprises.

\section{INTRODUCTION}

Small and medium enterprises (SMEs) composed 99.2\% of business establishments and contributed $56.4 \%$ of total employment in Malaysia [1]. According to the, Chief Executive Officer for SME Corporation Malaysia[2], it is expected that there will be an increment of $33.0 \%$ of SMEs contribution to the Gross Domestic Products as compared to the previous year, only $32.5 \%$. As a result, SMEs are expectedto contribute more to the country's export. Thus, the Malaysian government ensured that all funds through variety of programs provided by local banks are available to help SMEs expand and enable them to remain competitive [3][5]. Indeed, to ensure the success of SMEs in economic growth and development, their cooperation in providing accurate information through knowledge sharing in benchmarking are encouraged through many events organized by agencies under Ministry of International and Trade Industries (MITI).

The importance of benchmarking in Malaysia cannot be denied as its implementation is strongly supported by MITI through its agencies such as Malaysia Productivity Corporation (MPC) and SME Corporation Malaysia (SME Corp.). As for MPC, the Malaysian Benchmarking

Manuscript received May 20, 2013; revised July 19, 2013. This work was supported in part by the UniversitiSains Islam Malaysia under the University Grant PPP/FEM-1-16711.

Norailis $\mathrm{Ab}$. Wahab is with the Faculty of Economics and Muamalat, UniversitiSains Islam Malaysia (e-mail: norailis@usim.edu.my).

Syarizal Abdul Rahim is with the Faculty of Business and Entrepreneurship, Universiti Malaysia Kelantan, Malaysia.
Service(MBS) had been set up since 1997 to establish an information-sharing and reference centre as well as for benchmarking training and expertise for various industry backgrounds [6]. As for SME Corp, a benchmarking tool called SME Competitiveness Rating for Enhancement (SCORE) has been introduced to focus on seven areas which include business performance, financial capability, management capability, production capacity, technical capability, quality system and innovation among SMEs.

\section{LITERATURE REVIEW}

Different countries have different definition for SMEs due to a number of factors and some demographic criteria such as, size, location, structure, age, number of employees, sales volume, ownership through innovation and technology [7]. The importance of understanding "benchmarking" and its effects on a business had been highlighted in previous studies [8], [9]. In addition, SMEs definition changed from time to time based on the SMEs' significant contribution to the economic position in a particular country [10], [11]. Like Malaysia, the description is based on the number of employees and sales turnover which is slightly similar to the definitions used by United Kingdom, United States of America, Japan, China and Korea.

On the other hand, the roles of management are essential in the process of benchmarking [12]. Study has also indicated that managers may not quickly comprehend the appropriateness and applicability of benchmarking data in their organization due to incompatible factors involved in benchmarking such as size, location, structure, age, number of employees, sales volume and ownership. The managers' roles are beyond the exercise but also include growing dynamic changes that could transform SMEs from being efficient towards innovation [13]. Singh [14] also posited that the leadership in a company could determine the success rate of the exercise in the business. In addition, there were studies stressed the importance of benchmarking in the major business investment even though it meant different things to different people [4], [15].

Dattakumar and Jagadeesh [16] brought to light the issues that were not satisfactorily researched such as cost, duration, human resource and partner that need to be considered in benchmarking exercises. There are a number of scholars recommended tools for benchmarking [17]-[21]. Although Broderick et al. [22] and Lee et al. [23] mentioned that benchmarking among different type of business is important, it is difficult to apply in services. They also reasoned that, how benchmarking has been conducted among different scale of firms have to be considered with the aim of meeting its specific industry standards.

The areas of concern in this kind of activities are operational performance in manufacturing function, value 
management process, innovation and technology management, quality assessment, customer satisfaction and product development process [24]. Monkhouse [25] on the other hand reported that non-financial measures through benchmarking activity support the management decision making process. Sarkis [26] also agreed that there should be a set of widely acceptable characteristics in order to measure benchmarking effectiveness. For the above reasons, the objectives of this paper are; i) to examine the influence of demographic profile of SMEs on their practices of benchmarking; and ii) to identify the benchmarking focus areas of SMEs based on the benchmarking activities they have been involved in.

\section{MethodOLOGY}

The research was conducted by semi-structured interviews among thirty five SMEs. The process of data collection took almost two months, due to the process of getting responses from the SMEs that were willing to participate in the study. The interview sessions were divided into two main sections: (i) Section A was on demographic profile of the interviewees which comprises various types of industries. This part asked for background information, which includes type of ownership, age of business, initial capital, source of capital, time spent to manage business, number of employees and owners' education background. (ii) Section B concerned the generic benchmarking activities and related questions on the practice. Initially, to understand the characteristics of respondents, the data from section A were first described using appropriate descriptive analysis. Further analysis using NVivo software mainly involved the data from latter section collected with the aim of identifying and classifying responses regarding areas of benchmarking among participating SMEs.

\section{RESUlTS AND DisCUSSION}

Thirty five SMEs that participated in the study can be classified as company (51.4\%), sole proprietorship (37.1\%) and partnership (11.4\%) which consisted several type of businesses as viewed in Fig. 1.

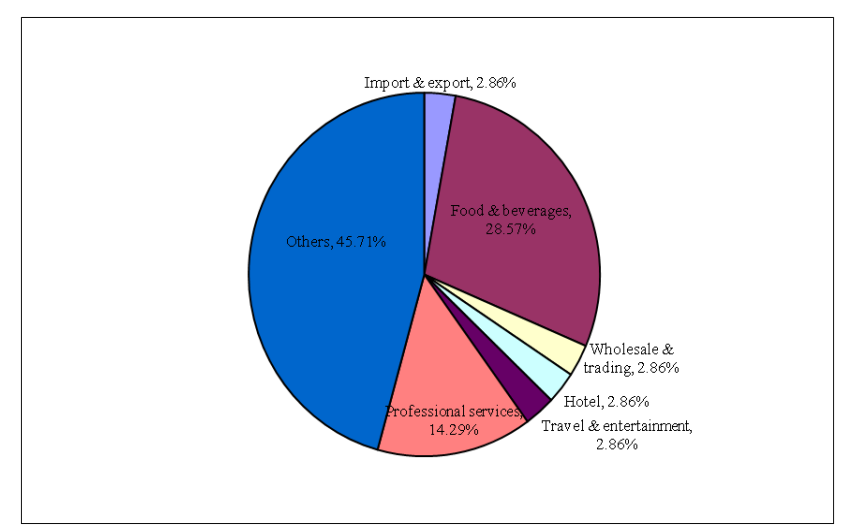

Fig. 1. Type of businesses.

Regarding the age of SMEs, more than half of the participated SMEs were between 0 to 3 years $(54.3 \%)$ followed by 4 to 6 years $(22.9 \%)$ and finally $20 \%$ of the SMEs were aged 10 years and above. A total of $74 \%$ were bootstrapped from personal savings or via borrowing from friends and relatives for initial capital. From the total, $32 \%$ dared to bootstrapped for the amount less than RM5,000 and RM10,001- RM20,000. However, merely 2.94\% had their initial capital from commercial banks where the amount was more than RM50,001. Surprisingly, more than half $(64.7 \%)$ of the business owners spent their time between 6 to 12 hours every day to manage their businesses. The above information on the characteristics of participated SMEs influenced the level of benchmarking activities had been implemented in their businesses.

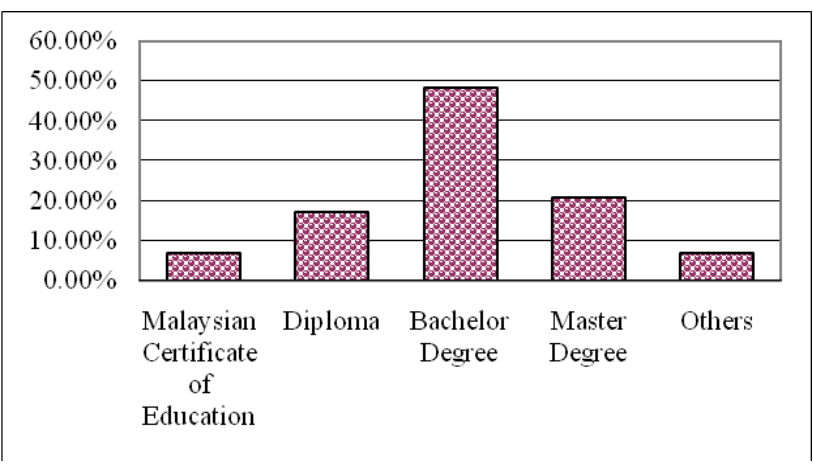

Fig. 2. Business owners' education background.

TABLE I: BEST RESPONSES ABOUT WHAT THE SMES LEARNED FROM BENCHMARKING ACTIVITIES

\begin{tabular}{|c|c|c|}
\hline Areas & The best responses & $\%$ \\
\hline Production & $\begin{array}{l}\text { 1. Practice policy of honesty. } \\
\text { 2. To satisfy customers and produce things } \\
\text { that are awesome. } \\
\text { 3. To maximize the quantity of production } \\
\text { with the limitations of employees' skills. } \\
\text { 4. Always update with the latest products and } \\
\text { technologies in the market. } \\
\text { 5. To have good contact with suppliers. }\end{array}$ & $32.6 \%$ \\
\hline $\begin{array}{l}\text { Operations } \\
\text { Management }\end{array}$ & $\begin{array}{l}\text { 1. Reduce the number of wastages during } \\
\text { production. } \\
\text { 2. To become a successful company and } \\
\text { employees obey instructions. } \\
\text { 3. Products must be produced on time. } \\
\text { 4. Motivation of staff. } \\
\text { 5. Good transportations, hired quality staff. }\end{array}$ & $17.0 \%$ \\
\hline Marketing & $\begin{array}{l}\text { 1. Try to have more publicity to extend } \\
\text { businesses. } \\
\text { 2. Diversity marketing skills. } \\
\text { 3. Direct access to business market without } \\
\text { middlemen. }\end{array}$ & $16.8 \%$ \\
\hline $\begin{array}{l}\text { Application of } \\
\text { ICT }\end{array}$ & $\begin{array}{l}\text { 1. Can get more customers to know about the } \\
\text { business and products. } \\
\text { 2. Target the market outside Malaysia by } \\
\text { using the internet. } \\
\text { 3. The production is efficient when machines } \\
\text { can produce more than targeted products per } \\
\text { hour. }\end{array}$ & $16.8 \%$ \\
\hline Financial & $\begin{array}{l}\text { 1. Need employee to maintain and oversee } \\
\text { the financial matters. } \\
\text { 2. Have good strategies for financial } \\
\text { management to avoid loss. } \\
\text { 3. Try not to be wasteful in purchasing } \\
\text { materials. }\end{array}$ & $10.0 \%$ \\
\hline Management & $\begin{array}{l}\text { 1. Document each business activity. } \\
\text { 2. Provide tasks for employees to make sure } \\
\text { they do their job. } \\
\text { 3. Stability in management. }\end{array}$ & $7.0 \%$ \\
\hline \multicolumn{2}{|c|}{ Total responses } & $100.0 \%$ \\
\hline
\end{tabular}

Referring to the above Fig. 2, nearly half of the business owners were first degree holders. It is important to know the educational background of the business owners because it 
showed the degree of their willingness in accepting new knowledge through training, seminars and workshops. These events were managed mostly by agencies under the Ministry of International Trade and Industry (MITI) such as Pocket Talks by SME Corp., Domestic Investment activities by Malaysian Investment Development Authority (MIDA) and Innovative and Creative Circle (ICC) Convention by Malaysia Productivity Corporation (MPC). The government delivers messages to SMEs to utilize skills and knowledge gained from these events so that they could add value to their products and services being offered in this sector.

The study also reveals that management (51.43\%) was chosen as the best driver of benchmarking in SMEs. Perhaps, the closeness of relationship between management, suppliers and customers encouraged management to support benchmarking rather than Chief Executive Officer, General Manager and even business owners in the enterprises. A total of $17.14 \%$ of the SMEs did not indicate the driver of benchmarking in the enterprises which could lead to several assumptions such as (i) absence of benchmarking activities; (ii) the goal of the business owners with respect to the business is only for survival in the local market; or (iii) imitating other businesses based on current demand.

Various responses were received during the semi-structured interviews. Table I shows six areas that the participating SMEs applied benchmarking activities since they started their businesses.

As a summary, the authors categorized the responses into six main areas that the SMEs focused on during their benchmarking activities. They simply took giant companies to be the best examples to be followed and this happened across all business types. For instance, Nestle is a big name in the food industry thus regardless of the differences in size, location, structure, age, number of employees, sales volume and ownership, the particular SMEs simply wanted to be like Nestle. Although this goal seems ambitious, it can be achieved. However, some actions need to be taken as well as higher involvement and collaboration with neighboring networks and support from government agencies through various activities organized from time to time.

\section{CONCLUSION}

As a conclusion, this study reveals that the most focused areas of benchmarking adoption depend on management's roles in supporting this activity continuously. Although, management supports are significant to benchmarking, the hindrances towards its effectiveness have to be removed carefully. However, the most important aspect is to promote a change of the current practice from non-existing benchmarking activities to a list of activities involving several areas, in particular learning from the best practices in the industry. SMEs are encouraged to adopt benchmarking as a tool to review their performance. Therefore, mindsets of the management should be changed by redirecting their focuses from internal matters such as standard, products and services to various international markets. Most probably, it should cover different types of relationships, trade regulations, customs, cultures and languages. In fact, they should take on the role of "the driver of economic changes and initiatives" and not just being contented as supporting industries. Besides that, SMEs have to maintain engagement with suppliers and customers as they are playing the key roles in the business process for long-term sustainability.

\section{ACKNOWLEDGEMENT}

In particular, the authors would like to thank UniversitiSains Islam Malaysia and SME Corporation Malaysia for the opportunities given as well as for those who participated in this study.

\section{REFERENCES}

[1] W. W. Shen. (2012). SOBA Workshops to feature wide range of speakers. [Online]. Available: http://biz.thestar.com.my/news/story.asp?file=/2012/6/9/business/114 45903\&sec=business. 09/06/2012.

[2] Kosmo, "Sumbangan PKS kepada KDNK naikkepada 33\%," Niaga, pp. 52, 2013.

[3] D. Desi. (2011). SMEs advised to view census in a positive light [Online]. Available: http://biz.thestar.com.my/news/story.asp?file=/2011/6/25/business/89 60990\&sec=business. 25/06/2011

[4] C. Cassell, S. Nadin, and M. O. Gray, "The use and effectiveness of benchmarking in SMEs," Benchmarking: An International Journal, vol. 8, no. 3, pp. 212-222, 2001.

[5] A. Anuar and Y. R. Mohd, "Manufacturing best practices in Malaysian small and medium enterprises (SMEs)," Benchmarking: An International Journal, vol. 18, no. 3, pp. 324-341, 2011.

[6] M. D. B. M. Khamis, N. K. Ab. Rahman, and A. R. Ismail, “A survey on benchmarking understanding and knowledge among Malaysian Automotive Components Manufacturing SMEs," European Journal of Scientific Research, vol. 33, no. 3, pp. 385-397, 2009.

[7] M. Zeinalnezhad, M. Mukhtar, and S. Sahran, "A study on benchmarking models and frameworks in industrial SMEs: Challenges and Issues," presented at The International Conference on Advanced Science, Engineering and Information, Hotel Equatorial Bangi-Putrajaya, Malaysia, 14-15 January 2011.

[8] J. W. Alstete, "Measurement benchmarks or "real" benchmarking? An examination of current perspectives," Benchmarking: An International Journal, vol. 15, no. 2, pp. 178-186, 2008.

[9] Carpinetti, C. R. Luiz, D. Melo, and M. Alexandre, "What to benchmark? A systematic approach and cases," Benchmarking: An International Journal, vol. 9, no. 3, pp. 244-255, 2002.

[10] A. Abdullah, "Measuring TQM implementation: A case study of Malaysian SMEs," Measuring Business Excellence, vol. 14, no. 3, pp. 3-15, 2010.

[11] K. Paula, "Revising the concept and forms of benchmarking," Benchmarking: An International Journal, vol. 10, no. 3, pp. 210-225, 2003.

[12] C. Cassell, S. Nadin, and M. O. Gray, "The use and effectiveness of benchmarking in SMEs," Benchmarking: An International Journal, vol. 8, no. 3, pp. 212-222, 2001.

[13] P. Hong and P. Jeong, "Supply chain management practices of SMEs: From a business growth perspective," Journal of Enterprise Information Management, vol. 19, no. 3, pp. 292-302, 2006

[14] S. S. Kumar, "Benchmarking leadership styles for organizational learning in Indian context," Benchmarking: An International Journal, vol. 17, no. 1, pp. 95-114, 2010.

[15] Md. Deros, B. M. Khamis, N. K. Ab. Rahman, and A. R. Ismail, “A survey on benchmarking understanding and knowledge among Malaysian Automotive Components Manufacturing SMEs," European Journal of Scientific Research, vol. 33, no. 3, pp. 385-397, 2009.

[16] R. Dattakumar and R. Jagadeesh, "A review of literature on benchmarking," Benchmarking: An International Journal, vol. 10, no. 3, pp. 176-209, 2003.

[17] R. C. Rickards, "BSC and benchmark development for an e-commerce SME," Benchmarking: An International Journal, vol. 14, no. 2, pp. 222-250, 2007.

[18] J. Razmi, M. Zairi, and Y. F. Jarrar, "The application of graphical techniques in evaluating benchmarking partners," Benchmarking, vol. 7, no. 4, pp. 304-314, 2000.

[19] P. Garengo, B. Stefano, S. Alessio, and B. Giovanni, "Benchmarking on managerial practices: A tool for SMEs," The TQM Magazine, vol. 17, no. 5, pp. 440-455, 2005.

[20] R. J. Bennett, "Expectation-based evaluation of SME advice and consultancy: An example of business link services," Journal of Small 
Business and Enterprise Development, vol. 14, no. 3, pp. 435-457, 2007.

[21] J. Thakkar, A. Kanda, and S. G. Desmukh, "Supply chain performance measurement framework for small and medium scale enterprises," Benchmarking: An International Journal, vol. 16, no. 5, pp. 702-723, 2009.

[22] A. Broderick, T. Garry, and M. Beasley, "The need for adaptive processes of benchmarking," Journal of Business \& Industrial Marketing, vol. 25, no. 5, pp. 324-337, 2010.

[23] Y. P. Lee, S. Zailani, and K. L. Soh, "Understanding Factors for Benchmarking Adoption: New Evidence from Malaysia," Benchmarking: An International Journal, vol. 13, no. 5, pp. 548-565, 2006.

[24] B. Md. Deros, S. M. Yusof, and A. Md. Salleh, "A benchmarking implementation framework for automotive manufacturing SMEs," Benchmarking: An International Journal, vol. 13, no. 4, pp. 396-430, 2006.

[25] M. Elaine, "The role of competitive benchmarking in small to medium-sized enterprises," Benchmarking for Quality Management \& Technology, vol. 2, no. 4, pp. 41-50, 1995.

[26] S. Joseph, "Benchmarking for agility," Benchmarking: An International Journal, vol. 8, no. 2, pp. 88-107, 2001.

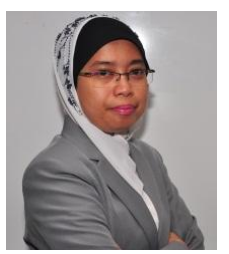

Norailis Ab. Wahab is a senior lecturer in the Faculty of Economics and Muamalat, UniversitiSains Islam Malaysia. She is a member of Malaysian Muamalat Association (MMA) and The Malaysian Consumer and Family Economics Association (MACFEA). She was born on September 4, 1978 in Negeri Sembilan, Malaysia. She attained her first degree in Industrial Economics in 2000 and Master in Science
(Productivity and Quality Enhancement) in the following year from UniversitiKebangsaan Malaysia. In the middle of 2009, she had been awarded $\mathrm{PhD}$ from the University of Stirling, Scotland. She joined SME Corporation Malaysia for three months in 2012 through USIM Academic Staff Attachment Program to gain industrial experiences and strengthen the networking with practitioners in small and medium enterprises (SMEs). This year, she has published two case studies on umrahmanagement and organizational issues in "Integrated Muamalat Case Study" by the PENERBIT UniversitiSains Islam Malaysia. She is actively involves in research on benchmarking, supply chain and umrahmanagement.

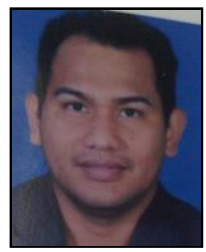

Syarizal Abdul Rahim is a lecturer in Universiti Malaysia Kelantan, Malaysia. He was born in Mentakab, Pahang in June, 1976. He obtained his first degree in Accounting from UniversitiTeknologi MARA (UiTM) in 1999. After ten years, he completed Master in Business Administration from Universiti Utara Malaysia (UUM). From 2002 to 2005, he was employed by Royal Bank of Scotland in Aberdeen. Then, he decided to change his direction by worked for Standard Chartered Bank in Singapore for four years. Before he joined the academics, he attached with Bank Muamalat Malaysia Berhad until early this year. This author is a member Automobile Association of Malaysia (AAM) due to high involvement in motorsports. His research interests are business and management particularly in motorsports. 